\title{
Pembuatan Air Purifier Dengan Air Sebagai Filter Untuk Kontrol Kesehatan Lingkungan
}

\author{
Furqaan Hamsyani* \\ Prodi Pengelolaan Lingkungan, Polteknik Pertanian \\ Negeri Samarinda, Samarinda, 75131 \\ furqaan@politanisamrinda.ac.id \\ *Corresponding author
}

\author{
Kemala Hadidjah \\ Prodi Pengelolaan Lingkungan, Polteknik Pertanian \\ Negeri Samarinda, Samarinda, 75131 \\ kemala.hadidjah@politanisamarinda.ac.id
}

\begin{abstract}
Abstrak-Pencemaran udara diartikan dengan turunnya kualitas udara sehingga udara mengalami penurunan mutu dalam penggunaannya dan akhirnya tidak dapat dipergunakan lagi sebagai mana mestinya sesuai dengan fungsinya. Untuk mengetahui tingkat pencemaran udara diperlukan suatu alat sebagai pemantau kualitas udara. Perkembangan pesat dalam alat dan cara kerja air purifier dalam ruang lingkup yang meluas sehingga air purifier yang seharusnya bermanfaat bagi lingkungan namun dalam kenyataannya merusak lingkungan. Kebutuhan manusia yang besar dalam hal alat dan peralatan namun tidak mengetahui dasar dari alat air purifier yang dapat diterapkan dan dikembangkan dengan bahan dan cara yang sederhana.
\end{abstract}

Kata Kunci- Alat, Air Purifier, Air, Cara kerja, Bahan ramah lingkungan.

\section{Pendahuluan}

Udara mempunyai arti yang sangat penting di dalam kehidupan makluk hidup dan keberadaan benda lainnya. Sehingga udara merupakan sumber daya alam yang harus dilindungi untuk kehidupan manusia dan makluk hidup lainnya. Hal ini bahwa pemanfaatannya harus dilakukan secara bijaksana dengan memperhitungkan kepentingan generasi sekarang dan yang akan datang. Untuk mendapatkan udara sesuai dengan tingkat kualitas yang diinginkan, maka pengendalian udara menjadi sangat penting untuk dilakukan.

Pencemaran udara diartikan dengan turunnya kualitas udara sehingga udara mengalami penurunan mutu dalam penggunaannya dan akhirnya tidak dapat dipergunakan lagi sebagai mana mestinya sesuai dengan fungsinya. Untuk mengetahui tingkat pencemaran udara diperlukan suatu alat sebagai pemantau kualitas udara. Di kota Samarinda terdapat alat pemantau berupa papan display yang dimiliki oleh badan lingkungan hidup yang menunjukkan indeks standar pencemaran udara. Namun, keberadaan papan display tersebut rusak dan tidak berfungsi. Oleh karena itu, muncul suatu ide untuk membuat alat pendeteksi pencemaran udara yang peka terhadap udara kotor.

Tersedianya alat-alat yang secara sederhana merupakan suatu keharusan sebagai dasar terapan alat yang modern, pada sebuah perguruan tinggi alat-alat sederhana yang selalu dikelola secara profesional berdampak positif bagi peningkatan alat, oleh karena itu keberadaan alat-alat yang dibuat dengan bahan dan cara yang sederhana, sehingga alat-alat sederhana tersebut merupakan landasan dasar dalam melakukan penelitian untuk menghasilkan suatu temuan yang berkualitas dan berpotensi komersial/paten guna mendukung tercapainya udara yang bersih.

\section{STUDI PUSTAKA}

Perkembangan pesat dalam alat dan cara kerja Air purifier dalam ruang lingkup yang meluas sehingga Air purifier yang seharusnya bermanfaat bagi lingkungan namun dalam kenyataannya meruak lingkungan. Kebutuhan manusia yang besar dalam hal alat dan peralatan namun tidak mengetahui dasar dari alat Air purifier yang dapat diterapkan dan dikembangkan dengan bahan dan cara yang sederhana.

\section{A. Pengertian Air Purifier}

Air purifier adalah perangkat rumah tangga yang dapat menghilangkan zat-zat kontaminan di udara sehingga dapat membuat udara menjadi bersih dan mencegah penyakit yang disebabkan kualitas udara yang buruk. Berdasarkan hasil pemantauan Kementerian Lingkungan Hidup melalui Air Quality Monitoring Station $(A Q M S)$, dari sepuluh kota besar di Indonesia, enam di antaranya yaitu Jakarta, Surabaya, Bandung, Medan, Jambi dan Pekanbaru hanya memiliki udara berkategori baik selama 22 sampai 62 hari dalam setahun atau tidak lebih dari 17 persen. Oleh karena itu, diciptakanlah Air purifier yang merupakan sebuah alat yang dapat membersihkan udara yang kita hirup. Tingkat kemampuan pembersih udaranya dapat mencapai 95 persen, mengeluarkan udara yang segar yang sudah bebas polusi.

\section{B. Prinsip Kerja Air Purifier}

Air Purifier berfungsi layaknya tumbuh-tumbuhan yang memproduksi udara segar bagi pernafasan kita. Tumbuh-tumbuhan rindang yang banyak tumbuh di daerah pedesaan ataupun pegunungan yang masih minim nilai polusinya ternyata menghasilkan ion-ion positif dan negatif yang bertujuan untuk menyeimbangkan komposisi udara yang kotor dengan memperbanyak unsur oksigen yang membuat udara yang dihirup terasa lebih segar. 
Cara ini yang menjadi basis dari penemuan air purifier. Dalam beberapa bentuk, Air Purifier berbentuk tunggal atau tergabung bersama alat pendingin (AC). Dikatakan Air Purifier karena teknologi ini memperkenalkan suatu filter yang terpasang di dalamnya sebagai filter pelengkap atau tambahan terhadap filter AC yang dianggap kurang efektif dalam mencegah pemasukan bakteri atau kuman patogen lainnya termasuk jamur pada udara yang dihasilkan. Filter yang bisa menyaring udara dari kotoran, debu, bau dan partikel-partikel kecil seperti bakteri dan kuman-kuman lain ini kebanyakan ditemukan dalam bentuk filter karbon, namun sekarang mulai banyak yang memodifikasi kembali filter ini termasuk dalam penambahan jumlah berlapis agar fungsinya semakin kuat dalam menyaring udara bersih. Untuk Air Purifier standar komponennya hanya berupa kipas angin yang berfungsi menggerakkan udara dan filter karbon sebagai penyaring udara.

\section{Macam-macam Air Purifier}

Beragam jenis Air Purifier yang ada di pasaran turut menentukan fungsi serta kualitasnya dalam menyaring udara. Sebab seperti yang kita tahu, polutan - polutan seperti asap, debu, spora jamur, serbuk, dan zat kimia terkadang tidak semuanya dapat tersaring dengan baik oleh Air Purifier tertentu. Padahal, semua partikel tersebut dalpat mengancam kesehatan kita. Untuk itu, selalu pahami betul tipe Air Purifier yang akan Anda beli. Beberapa Air Purifier memang memiliki kualitas yang baik dan dapat menyaring debu secara maksimal, namun membutuhkan konsumsi energi yang lebih besar serta penggantian filter secara berkala. Maka, agar Anda tak salah dalam memilih, berikut ini beragam jenis Air Purifier beserta cara kerjanya dan keuntungan serta kekurangan masing-masing.

1. Air Purifier dengan Pengendap Elektrostatis

(Electrostatic Presipator)

Air Purifier yang menggunakan pengendap elektrostatis ini menggunakan tenaga listrik untuk memberikan ion-ion pada partikel saat partikel melewati perangkat ini. Partikel yang telah diberi ion tersebut akan mudah untuk tertarik dan terperangkap pada lempengan logam di air purifier. Saat semua partikel sudah terkumpul dalam lempengan logam tadi, pemilik bisa membersihkan lempengan tersebut dari polutan dengan cara mengelapnya kemudian membuangnya. Kemudian, taruh kembali lempengan logam tersebut di tempat semula. Mungkin Air Purifier dengan Pengendap Elektrostatis ini cukup efektif dalam menyaring polutan, terutama yang berupa bau, partikel halus, gas, atau bahan kimia yang ada di udara. Namun, berdasarkan penelitian dari California Environmental Protection Agency, 2002, Air Purifier jenis ini bisa menghasilkan ozon sebagai produk sampingan. Ozon sendiri merupakan gas yang berbahaya dan bisa beracun. Gas ini terdiri dari 3 atom oksigen yang saling berikatan. Orang - orang yang terlalu lama menghirup gas ini bisa mengalami gangguan pada kesehatannya, terutama bila ozon diproduksi dalam kadar yang tinggi.

\section{Air Purifier dengan Ionizers/ Ion Generator}

Ionizers atau biasa juga disebut ion generator memproduksi ion-ion bertenaga listrik yang kemudian didistribusikan ke seluruh ruangan. Sekali ion tersebut menyebar di udara, maka ion ini akan menangkap dan mengikat polutan yang berupa partikel halus. Kemudian, ion dan polutan tersebut akan menjadi satu dan jatuh ke bawah/lantai. Sama seperti Air Purifier dengan Pengendap Elektrostatis, Air Purifier dengan ionizer ini pun mampu menghilangkan partikel, debu, virus, asap rokok, maupun bakteri. Namun, efek sampingnya, perangkat ini juga menghasilkan ozon sebagai produk sampingan. Kelemahan lain dari alat ini adalah partikel atau debu yang berhasil diikat akan jatuh ke lantai, furnitur, karpet, tempat tidur, dan sebagainya. Sehingga, butuh waktu ekstra untuk membersihkannya.

\section{Air Purifier dengan Ozon}

Meskipun kedua jenis Air Purifier di atas sama-sama memproduksi ozon sebagai produk sampingannya, jenis Air Purifier lain yang tidak menggunakan filter pada mekanismenya justru menggunakan ozon ini sebagai generator. Air Purifier tersebut biasanya menggunakan sinar ultraviolet, energi listrik, atau justru kombinasi dari keduanya. Kemudian, dihasilkanlah molekul-molekul ozon yang dilepas ke udara. Molekul ozon yang dilepas di udara mampu membersihkan udara dengan cara mengubah partikel kimia, debu, dan bakteri, menjadi substansi yang tidak berbahaya. Namun sekali lagi, ozon ini cukup berbahaya dan bisa berdampak bagi kesehatan. Ozon ini sering kali dikaitkan dengan gangguan kesehatan pada hidung, mata, paru-paru, hingga tenggorokan. Bahkan yang lebih parah, ozon ini dapat memicu asma. Untuk itu, Air Purifier dengan ozon generator ini sangat tidak direkomendasikan bagi Anda yang memiliki anak kecil, karena efeknya akan lebih terasa oleh anak-anak yang masih cukup rentan. Selain itu, penggunaan Air Purifier jenis ini juga perlu dihindari bagi mereka yang telah berusia lanjut atau memiliki masalah dengan kekebalan tubuh.

\section{Air Purifier dengan fitur Ultraviolet}

Air Purifier dengan fitur Ultraviolet ini bekerja dengan memancarkan sinar UV untuk membunuh partikel-partikel biologis seperti debu, bakteri, spora jamur, virus, dan lain-lain. Keuntungan dari penggunaan Air Purifier tipe ini adalah tidak adanya ozon sebagai produk sampingan. Namun, jenis ini kurang efektif dalam menyaring debu, sebab level UV yang dipancarkannya biasanya rendah dan belum cukup untuk membunuh partikel biologis secara maksimal.

5. Air purifiers dengan Photocatalytic Oxidation (PCO)

Air Purifiers jenis ini menggunakan kombinasi dari sinar UV dan sebuah katalis, biasanya titanium oksida, untuk membersihkan udara. Sinar UV dan katalis ini bekerjasama agar bisa bereaksi dengan gas serta partikel berbahaya yang ada di udara. Hasil dari reaksi mampu menghilangkan kadar racun dan bahaya pada gas dan partikel tersebut tanpa menghilangkannya dari udara. Sehingga, gas dan partikel tersebut sebenarnya masih tetap di udara. Beberapa penelitian menyebutkan Air Purifier ini kurang maksimal dalam menyaring debu dan 
polutan lain. Meski begitu Brinke, 1995 menemukan bahwa sejauh ini, Air Purifer dengan PCO ini adalah jenis Air Purifier yang paling baik.

\section{Pengertian Udara Bersih}

Udara yang bersih adalah udara yang mengandung banyak manfaat bagi manusia. Udara yang bersih besar dari segala macam sesuatu yang tidak dibutuhkan oleh manusia, baik itu berupa zat-zat atau partikel-partikel padat seperti debu, kotoran, dan lainnya maupun berupa gas-gas yang tidak diperlukan karena sifatnya yang merugikan, seperti karbondioksida, karbonmonoksida, dan gas-gas yang berbahaya lainnya. Udara yang bersih dan sehat ini memiliki ciri khas khusus yang membedakannya dengan udara yang cenderung tidak baik atau cenderung tercemar.

\section{E. Ciri- ciri Udara Bersih dan Sehat}

Udara yang bersih lagi sehat berbeda dengan udara yang biasa kita hirup dalam suasana hiruk pikuk, seperti daerah perkotaan. Udara yang bersih dan sehat ini merupakan udara yang murni, sejuk, dan terasa segar apabila dihirup dan masuk ke paru-paru.

Udara bersih merupakan udara yang murni dan belum tercampur dengan berbagai benda asing, baik dalam bentuk padat, cair, maupun gas, serta zat-zat lain yang bersifat merugikan. Udara yang bersih dan sehat ini tentulah berbeda ciri-cirinya dengan udara yang tercemar atau kotor. Beberapa ciri ciri udara bersih dan sehat antara lain:

\section{Tidak berwarna}

Ciri pertama dari udara bersih dan juga sehat adalah tidak mempunyai warna atau tidak berwarna. Udara yang bersih ini adalah udara yang murni. Udara yang murni merupakan udara yang tidak mempunyai warna, sehingga jika terdapat warna pada udara maka udara tersebut maka udara tersebut tidak baik atau tidak sehat. Udara yang mempunyai warna merupakan udara yang telah tercampur dengan gas-gas ataupun benda lainnya tertentu sehingga menimbulkan warna yang terasa asing dan merusak kemurnian udara.

\section{Tidak berbau}

Ciri yang kedua yang dimiliki oleh udara adalah tidak berbau. Udara yang bersih merupakan udara yang terasa segar apabila dihirup, dan tentu saja tidak berbau. Udara yang apabila dicium akan berbau maka udara itu bukanlah udara yang yang murni. Udara yang berbau berarti udara yang telah tercampur dengan berbagai zat lain (umumnya yang berupa gas), maka udara yang berbau bukanlan udara yang murni lagi.

\section{Tidak berasa}

Ciri selanjutnya dari udara adalah udara tidak mempunyai rasa. Udara yang murni adalah udara yang tidak mempunyai rasa apapun, sehingga apabila kita merasakan udara yang dihirup mempunyai rasa, maka udara tersebut bukanlah udara yang murni lagi. Indikasi rasa pada udara ini dapat dirasakan melalui bau pada udara tersebut. Apabila udara yang dihirup mempunyai bau tertentu, hal itu menandakan bahwa udara tersebut juga mempunyai rasa.

\section{Tidak tercampur dengan benda asing}

Ciri yang paling umum untuk menyatakan sesuatu hal yang murni adalah tidak tercampur dengan benda-benda asing lainnya. Benda-benda asing ini adalah benda yang dapat mempengaruhi kemurnian udara tersebut, baik itu gas, cairan, maupun benda padat lainnya. Campurnya udara dengan benda-benda yang bersifat lainnya ini menyebabkan udara menjadi tidak bersih dan juga tidak menyehatkan. Hal ini karena benda-benda yang tercampur di dalamnya ini terkadang mempunyai sifat yang membahayakan kesehatan. Dan udara yang tercampur dengan benda-benda lainnya ini terkadang menimbulkan perubahan pada warna, bau dan rasa sehingga dapat diketahui, namun terkadang tidak menimbulkan apapun sehingga sulit untuk diketahui.

5. Terasa segar apabila dihirup

Udara yang bersih dan sehat merupakan udara yang terasa segar apabila dihirup. Berbeda dengan udara yang yang telah tercemar yang apabila dihirup maka akan menyesakkan dada. Udara bersih kesegarannya masih tetap terjaga hingga bisa menenangkan pikiran kita dan mengalirkan oksigen murni pada tubuh.

6. Terasa sejuk

Udara yang bersih adalah udara yang terasa sejuk di badan. Berbeda dengan udara yang telah tercemar yang terasa panas di badan. Udara bersih dan sehat akan terasa sejuk apabila menyentuh permukaan kulit. Udara bersih biasanya dapat ditemui di daerah-daerah yang memiliki banyak pepohonan, maka di daerah tersebut biasanya akan terasa sejuk.

7. Dapat digunakan sebagai terapi kesehatan tubuh

Udara yang bersih dapat dimanfaatkan sebagai alat terapi kesehatan. Maka dari itulah udara yang bersih dan sehat ini mempunyai ciri dimanfaatkan sebagai bahan terapi untuk kesehatan tubuh. Beberapa manfaat yang dimiliki oleh udara bersih untuk kesehatan tubuh adalah untuk menjaga ketenangan, menghalau ketegangan, meningkatkan kekebalan atau daya tahan tubuh dan juga menambah energi.

Udara yang bersih dan menyehatkan biasanya dapat ditemui di tempat-tempat yang mempunyai banyak pepohonan dan juga tumbuhan hijau. Hal ini karena tumbuhan hijaulah yang berperan untuk memproduksi udara yang bersih ini. Udara yang bersih juga sarat dengan oksigen sehingga terasa segar di badan.

\section{METODOLOGI}

Penelitian pembuatan alat air purifier dengan bahan sederhana, dilakukan dan pengujian di Program Studi Pengelolaan Lingkungan Politeknik Pertanian Negeri Samarinda. Meliputi : studi literatur tentang alat air purifier, pencarian bahan-bahan sisa yang sederhana serta yang ramah lingkungan, proses pembuatan alat air purifier, pengujian alat, kelayakan alat, dan perbaikan kelayakan alat. Bahan-bahan yang digunakan dalam penelitian ini adalah literatur yang mendukung penelitian ini, bahan-bahan sisa dan sederhana yang ramah lingkungan. Secara garis besar tahapan dalam penelitian yang direncanakan adalah seperti pada diagram alir dapat dilihat pada gambar 1 . 


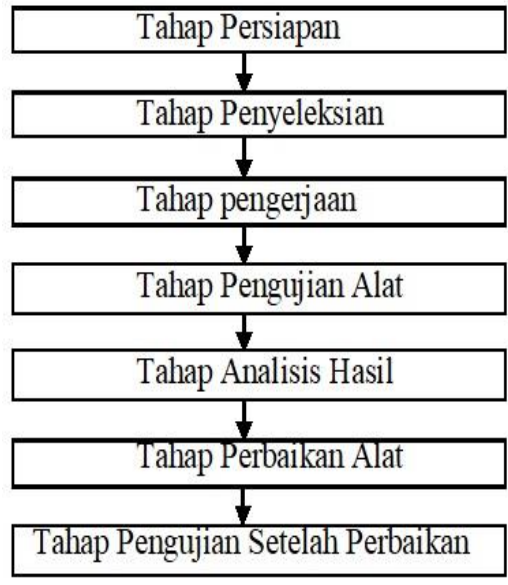

Gambar 1. Gambar diagram alir penelitian

Adapun penjelasan diagram alir di atas adalah sebagai berikut ini:

1. Tahap persiapan, tahapan ini dilakukan studi literatur yang berhubungan alat air purifier, apakah dengan rencana atau desain yang dibuat sudah ada ataukah tidak ada atau pengembangan dari alat yang sudah ada, kemudian mengumpulkan dan penyiapan semua bahan sisa dan ramah lingkungan;

2. Tahap penyeleksian, desain yang sudah ada dengan sedetail dan sewajarnya sehingga tidak terjadi plagiat dan menyeleksi semua bahan-bahan sisa dan ramah lingkungan dengan uji tertentu;

3. Tahap pengerjaan, bahan-bahan sisa dan ramah lingkungan yang sudah teruji dengan uji tertentu berdasarkan dengan desain yang dibuat.

4. Tahap pengujian alat, dilaksanakan secara sederhana di Program Studi Pengelolaan Lingkungan Politeknik Pertanian Negeri Samarinda.

5. Tahap analisis hasil, pengujian kecepatan uadara terhisap dari alat air purifier sederhana sebagai sebuah indikator awal dan yang keluar dari alat.

6. Tahap perbaikan alat, setelah di uji alat tersebut alat maka dilakukan perbaikan kekurangan pada alat air purifier.

7. Tahap pengujian setelah perbaikan, setelah dilakukan perbaikan terhadap kekurangan alat maka dilakukan lagi menguji ulang air purifier sederhana.

\section{HASIL DAN PEMBAHASAN}

\section{A. Pembersih Udara Dalam Ruangan (Air Purifier)}

Dari diagram alir yang terdapat dimetode penelitian yang terlaksana yaitu tahap persiapan, tahap penyeleksian, dan tahap pengerjaan, tahap pengujian alat, tahap analisis hasil, perbaikan alat, serta pengujian dimana tahap terlaksana $100 \%$, secara sedehana cara kerja alat dapat dilihat pada gambar 2.

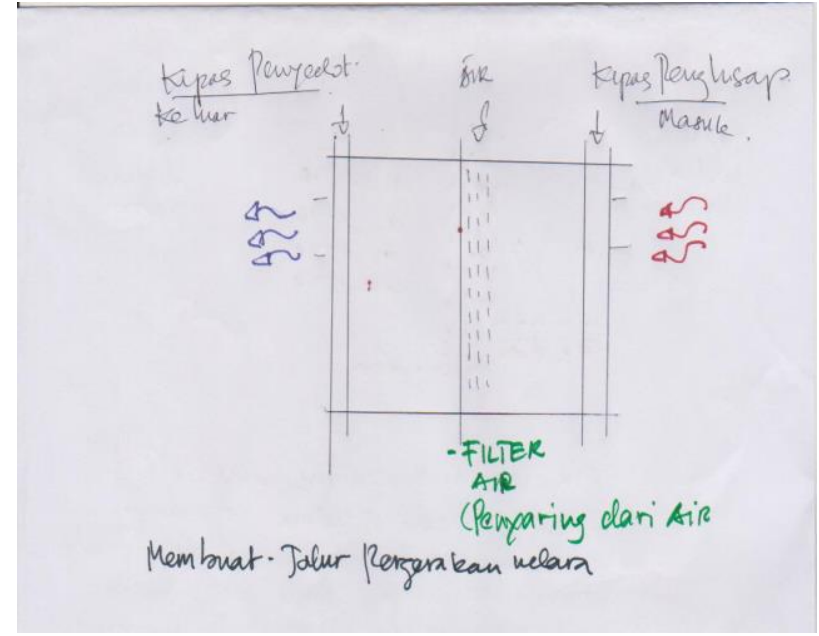

Gambar 2. Cara kerja sederhana air purifier

Dari gambar diatas dapat dilihat bahwa udara dimasukkan ke dalam alat sedehana dengan kipas penghisap kemudian ditabrakkan dengan melewati aliran waterfall dengan dibantu kipas penyedot untuk meningkatkan kecepatan udara menjadi cepat sehingga udara mampu melewati waterfall.

Dari hasil penelitian terlihat bahwa udara yang masuk kedalam alat setiap 2 menit dimana menit pertama adalah $1,24 \mathrm{~m} / \mathrm{s}$ dan menit yang kedua $1,25 \mathrm{~m} / \mathrm{s}$, menit ketiga $1,27 \mathrm{~m} / \mathrm{s}$, menit keempat $1,24 \mathrm{~m} / \mathrm{s}$, menit kelima $1,24 \mathrm{~m} / \mathrm{s}$, sedangkan untuk suhu udara dalam ruangan yang masuk ke dalam alat setiap 2 menit dimana menit pertama adalah $30,4{ }^{\circ} \mathrm{C}$ dan menit yang kedua $30,6^{\circ} \mathrm{C}$, menit ketiga $30,5{ }^{\circ} \mathrm{C}$, menit keempat $30,4{ }^{\circ} \mathrm{C}$, menit kelima $30,4{ }^{\circ} \mathrm{C}$, dan untuk suhu udara dari alat setiap 2 menit dimana menit pertama adalah $29,7{ }^{\circ} \mathrm{C}$ dan menit yang kedua $29,9^{\circ} \mathrm{C}$, menit ketiga $29,7^{\circ} \mathrm{C}$, menit keempat $29,8^{\circ} \mathrm{C}$, menit kelima $29,7^{\circ} \mathrm{C}$. Kecepatan udara keluar alat setiap 2 menit, dimana menit pertama adalah 2,01 $\mathrm{m} / \mathrm{s}$ dan menit yang kedua $2,01 \mathrm{~m} / \mathrm{s}$, menit ketiga 2,01 $\mathrm{m} / \mathrm{s}$, menit keempat $2,01 \mathrm{~m} / \mathrm{s}$, menit kelima $2,01 \mathrm{~cm} / \mathrm{s}$ dapat dilihat pada gambar 3 dan 4 .

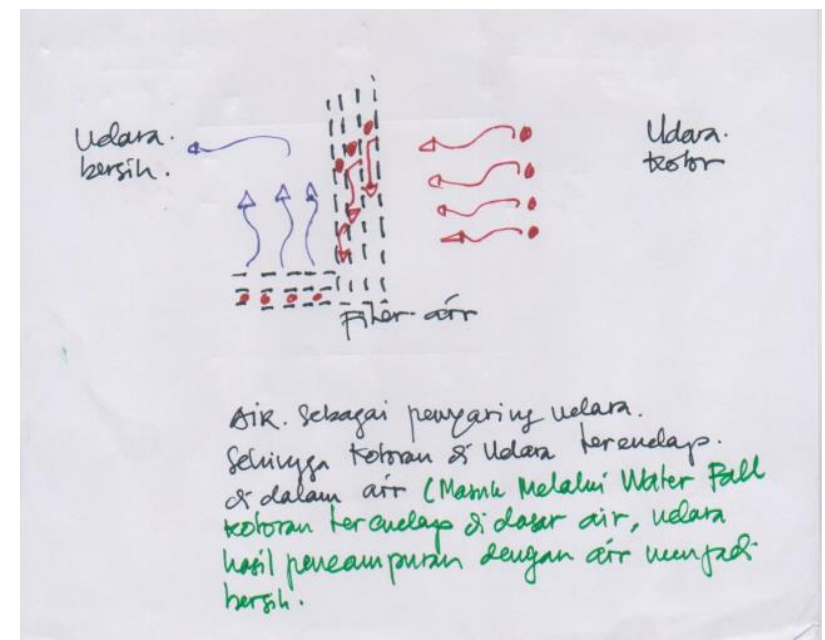

Gambar 3. Cara Kerja Udara Melewati Waterfall. 


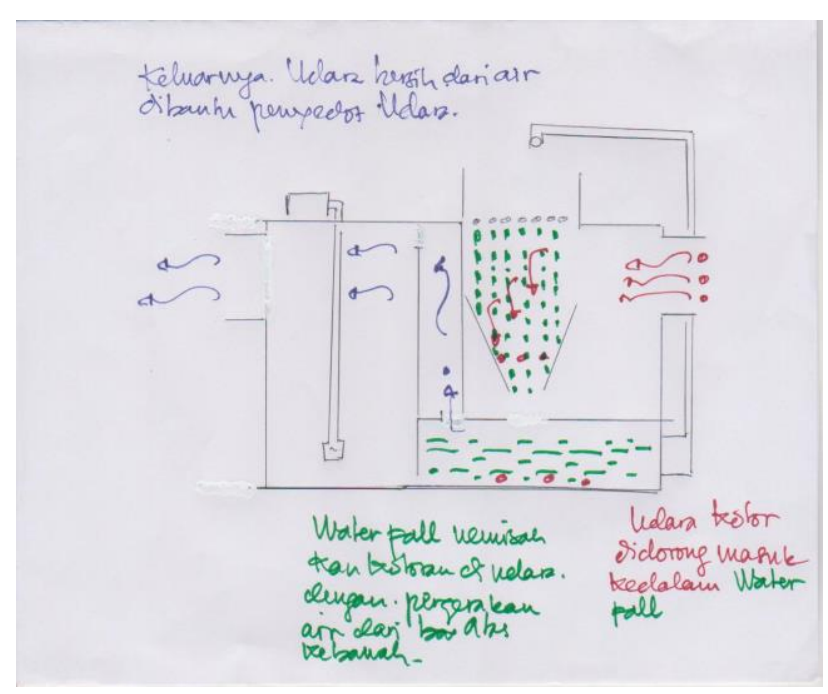

Gambar 4. Cara Kerja Secara Menyeluruh.

Hasil penelitian dapat dilihat pada tabel 1 .

Tabel 1. Hasil pengamatan terhadap alat air purifier dengan alat anemometer dan sound level meter.

\begin{tabular}{lcccc}
\hline $\begin{array}{c}\text { Waktu } \\
\text { Per 2 } \\
\text { Menit }\end{array}$ & $\begin{array}{c}\text { Udara } \\
\text { Masuk } \\
(\mathrm{m} / \mathrm{s})\end{array}$ & $\begin{array}{c}\text { Waterfall } \\
\left({ }^{\circ} \mathrm{C}\right)\end{array}$ & $\begin{array}{c}\text { Setelah } \\
\text { Waterfall } \\
\left({ }^{\circ} \mathrm{C}\right)\end{array}$ & $\begin{array}{c}\text { Udara } \\
\text { Keluar } \\
(\mathrm{m} / \mathrm{s})\end{array}$ \\
\hline M1 (2) & 1,24 & 30,4 & 29,7 & 2,01 \\
M2 (4) & 1,25 & 30,6 & 29,9 & 2,01 \\
M3 (6) & 1,27 & 30,5 & 29,7 & 2,01 \\
M4 (8) & 1,24 & 30,4 & 29,8 & 2,01 \\
M5 (10) & 1,24 & 30,4 & 29,7 & 2,01 \\
\hline
\end{tabular}

\section{B. Indoor Air Quality}

Indoor air quality atau kualitas udara dalam suatu ruangan adalah salah satu aspek keilmuan yang memfokuskan pada kualitas atau mutu udara dalam suatu ruang yang akan dimasukkan kedalam ruang atau gedung yang di tempati oleh manusia (Idham, 2001).

Menurut National Health Medical Research Council (2010), mendefinisikan udara dalam ruangan adalah udara yang berada dalam suatu ruang gedung yang ditempati oleh sekelompok orang yang memiliki tingkat kesehatan yang berbeda-beda selama minimal satu jam. Ruang gedung yang dimaksud dalam pengertian ini meliputi sekolah, restoran, rumah, gedung untuk umum, hotel, rumah sakit, dan perkantoran, tidak termasuk tempat kerja atau tempat-tempat yang mengacu pada standar kesehatan kerja.

Pengertian indoor air quality dari USA Environmental Protection Agency (EPA), 1997 adalah hasil interaksi antara tempat, suhu, sistem gedung (baik disain asli maupun modifikasi terhadap struktur dan sistem mekanik), teknik konstruksi, sumber kontaminan (material, peralatan gedung, kelembaban proses, dan aktifitas di dalam gedung serta sumber dari luar) dan pekerja. Kualitas udara di dalam ruangan merupakan gambaran dari kondisi udara di dalam ruangan yang memadai untuk dihuni oleh manusia. Definisi dan standard mengenai kualitas udara dalam ruangan yang memadai yang umum digunakan adalah berdasarkan standar ASHRAE 62-2001 mengenai ventilasi untuk kualitas udara yang memadai (Ventilation for acceptable indoor air quality). Pengertian kualitas udara dalam ruang yang memadai menurut standar tersebut adalah udara dimana tidak ada kontaminan pada konsentrasi yang membahayakan yang sudah ditetapkan oleh para ahli dimana sebesar $80 \%$ atau lebih para penghuni suatu gedung merasakan ketidakpuasan dan ketidaknyamanan.

Sumber kontaminan udara dalam ruangan, pencemaran udara dibagi menjadi dua yaitu pencemaran udara luar ruangan dan pencemaran udara dalam ruang. Pencemaran udara dalam ruang, walaupun tidak berhubungan langsung dengan emisi global, namun sangat penting untuk menentukan keterpajanan seseorang. Di daerah perkotaan isu mengenai pencemaran udara dalam ruang berkembang pesat mengingat sebagian besar masyarakat menghabiskan waktunya lebih banyak didalam ruangan terutama dalam ruang kerja perkantoran dan industri (Kusnoputranto, 2000). Berikut adalah beberapa sumber kontaminan dalam udara menurut EPA (1997), sumber dari luar bangunan, yang terdiri dari :

1. Udara luar bangunan yang terkontaminasi seperti debu, spons jamur, kontaminasi industri, dan gas buang kendaraan.

2. Emisi dari sumber di sekitar banguan seperti gas buangan kendaraan pada area sekitar atau area parkir, tempat bongkar muat barang, bau dari tempat pembuangan sampah, udara buangan, yang berasal dari gedung itu sendiri atau gedung sebelahnya yang dimasukkan kembali, kotoran di sekitar area intake udara luar bangunan.

3. Soil gas seperti radon, kebocoran gas dari bahan bakar yang disimpan di bawah tanah, kontaminan yang berasal dari penggunaan lahan sebelumnya, dan pestisida.

4. Kelembaban atau rembesan air yang memicu perkembangan mikroba.

Peralatan, yang terdiri dari :

1. Peralatan HVAC seperti debu atau kotoran pada saluran atau komponen lain, pertumbuhan mikroba pada humidifier, saluran, penggunaan biosida, penggunaan produk pembersih yang tidak sesuai ketentuan, sistem ventilasi yang kurang baik, alat pendingin (refriginerator) yang bocor.

2. Peralatan non-HVAC seperti emisi dari peralatan kantor (VOCs, ozon), suplai (pelarut, toner, ammonia), emisi dari took, laboratorium, proses pembersihan, mesin penggerak elevator dan sistem mekanik lainnya.

Kegiatan manusia, yang terdiri dari :

1. Kegiatan personal seperti merokok, memasak, aroma kosmetik dan bau badan

2. Kegiatan housekeeping seperti bahan pembersih, emisi dari gudang penyimpanan bahn suplai atau sampah, penggunaan pengharum, debu atau kotoran udara dari menyapu (vacumming).

3. Kegiatan pemeliharaan seperti mikroorganisme dalam uap air akibat kurangnya pemeliharaan cooling tower, 
debu atau kotoran udara,

4. VOCs dari penggunaan perekat dan cat, pestisida dari kegiatan pengendalian hama, emisi dari gudang penyimpanan.

Komponen bangunan dan peralatan interior, yang terdiri dari :

1. Lokasi yang menghasilkan debu atau serat seperti permukaan yang dilapisi (penggunaan karpet, tirai, dan bahan tekstil lainnya), peralatan interior yang sudah tua atau rusak, bahan yang mengandung asbestos.

2. Bahan kimia dari komponen bangunan atau peralatan interior seperti VOCs atau senyawa anorganik.

Sumber lainnya, yang terdiri dari :

1. Kejadian kecelakaan seperti tumpahan cairan, pertumbuhan mikroba akibat banjir, kebocoran atap atau pipa, kerusakan akibat kebakaran

2. Penggunaan area secara khusus seperti area merokok, ruang print, laboratorium dan penyiapan makanan

3. Emisi dari peralatan interior yang baru, bau dari uap organic maupun anorganik dari cat atau bahan perekat.

Hasil pemeriksaan The National Institute of Occupational Safety and Health (NIOSH), menyebutkan ada 5 sumber pencemaran di dalam ruangan yaitu (Aditama, 2002):

1. Pencemaran dari alat-alat di dalam gedung seperti asap rokok, pestisida, bahan-bahan pembersih ruangan.

2. Pencemaran di luar gedung meliputi masuknya gas buangan kendaraan bermotor, gas dari cerobong asap atau dapur yang terletak di dekat gedung, dimana kesemuanya dapat terjadi akibat penempatan lokasi lubang udara yang tidak tepat.

3. Pencemaran akibat bahan bangunan meliputi pencemaran formaldehid, lem, asbes, fibreglass dan bahan-bahan lain yang merupakan komponen pembentuk gedung tersebut.

4. Pencemaran akibat mikroba dapat berupa bakteri, jamur, protozoa dan produk mikroba lainnya yang dapat ditemukan di saluran udara dan alat pendingin beserta seluruh sistemnya.

5. Gangguan ventilasi udara berupa kurangnya udara segar yang masuk, serta buruknya distribusi udara dan kurangnya perawatan sistem ventilasi udara

C. Faktor-Faktor Yang Mempengaruhi Kualitas Udara Dalam Ruangan (Kualitas Fisik)

1. Suhu / Temperatur

Panas dalam ruangan diproduksi oleh tubuh sebagai proses biokimia yang berhubungan pembentukan jaringan, konversi energi dan kerja otot. Panas yang dihasilkan oleh proses metabolism dapat dibagi menjadi dua yaitu metabolisme basal misalnya proses-proses otomatis seperti denyut dan metabolisme maskular seperti mengontrol kerja otot (Fardiaz, 1992). Namun dari semua energi yang dihasilkan tubuh hanya 20\% saja yang dipergunakan dan sisanya akan dibuang ke lingkungan (Arismunandar dan Saito, 2002). Suhu udara sangat berperan dalam kenyamanan bekerja. Menurut
Heryuni (1993) untuk lingkungan kerja disarankan mempunyai suhu kering $22-26^{\circ} \mathrm{C}$ dan suhu basah 21 $24^{\circ} \mathrm{C}$. Sedangkan menurut Mukono (1993), temperatur yang dianggap nyaman untuk bekerja adalah $23-25^{\circ} \mathrm{C}$. Menurut KepMenKes No 261/Menkes/SK/II/1998 suhu ruangan adalah $22-26^{\circ} \mathrm{C}$.

Perubahan suhu lebih dari $7^{\circ} \mathrm{C}$ secara tiba-tiba dapat menyebabkan pengerutan saluran darah, sehingga perbedaan suhu dalam dan luar ruangan sebaiknya kurang dari $7^{\circ} \mathrm{C}$. Tingkat panas didominasi oleh temperatur sekitarnya. Namun demikian, standar udara kering atau pengukuran temperatur ambient udara kering sering tidak cukup sebagai indikator untuk kriteria tingkat kenyamanan. Temperatur diukur dengan menggunakan thermometer untuk mewakili keadaan penghuni.

2. Kecepatan Aliran Udara

Kecepatan alir udara mempengaruhi gerakan udara dan pergantian udara dalam ruang. Besarnya berkisar antara 0,15 sampai dengan 1,5 meter/detik, dapat dikatakan nyaman. Kecepatan udara kurang dari 0,1 meter/detik atau lebih rendah menjadikan ruangan tidak nyaman karena tidak ada pergerakan udara. Sebaliknya bila kecepatan udara terlalu tinggi akan menyebabkan kebisingan di dalam ruangan (Arismunandar dan Saito, 2002). Menurut keputusan Menteri Kesehatan No. 261/ Menkes/SK/II/1998, kecepatan aliran udara yang normal adalah 0,15-0,25 meter/detik. Tingkat kenyamanan panas dipengaruhi oleh kecepatan udara. Ketika pendinginan diperlukan, dapat dilakukan peningkatan kecepatan udara.

\section{Kelembaban Udara}

Air bukan merupakan polutan, namun uap air merupakan pelarut untuk berbagai polutan dan dapat mempengaruhi konsentrasi polutan di udara. Uap air dapat menumbuhkan dan mempertahankan mikroorganisme di udara dan juga dapat melepaskan senyawa-senyawa volatile yang berasal dari bahan bangunan seperti formaldehyde, ammonia, dan senyawa lainya yang mudah menguap, sehingga kelembaban yang tinggi melarutkan senyawa kimia lain lalu menjadi uap dan akan terpapar pada pekerja (Fardiaz, 1992).

Pada lingkungan yang ada dalam ruangan, sekitar $25 \%$ dari panas tubuh diemisikan oleh transprasi. Sebagai temperatur ambient dan meningkatnya aktivitas metabolisme, transpirasi yang hilang meningkat 50\%$80 \%$ dari total emisi tubuh. Kehilangan panas karena transpirasi ditandai dengan tingginya kelembaban relatif (Arismunandar dan Saito, 2002).

Kelembaban udara yang relatif rendah yaitu kurang dari $20 \%$ dapat menyebabkan kekeringan selaput lender membrane. Sedangkan kelembaban yang tinggi dapat meningkatkan pertumbuhan mikroorganisme dan pelepasan formaldehid dari material bangunan (Molhave,1990).

Menurut Heryuni (1993) berdasarkan surat edaran Menteri Tenaga Kerja, Transmigrasi dan Koperasi No. SE-01/Men/1987 tentang Nilai Ambang Batas (NAB) yang berlaku untuk lingkungan kerja di industri adalah kelembaban $65 \%-95 \%$ dengan kisaran suhu $26^{\circ}-30^{\circ} \mathrm{C}$. 
Sedangkan menurut KepMenKes No.261/MenKes/ SK/II/1998 untuk kelembaban adalah 40\%-60\%.

4. Kalor Radiasi

Beban kalor radiasi rata-rata diperhitungkan dengan perancangan sistem ventilasi. Hal ini berkaitan dengan besarnya kalor diterima udara dalam ruangan. Semakin tinggi kalor yang diterima maka beban AC semakin besar sehingga pengelolaan gedung kurang efisien (Arismunandar dan Saito, 2002). Sumber penghasil kalor radiasi antara lain reaksi eksotermik dari bahan-bahan kimia, kalor yang dilepas lampu, sistem pemanasan ruang dan alat-alat, sinar matahari yang masuk, serta tungku/kompor untuk memasak. Selain itu terdapat pula sumber yang dapat menyerap kalor radiasi, yaitu jendela yang terbuka, dinding yang tidak dilapisi dengan baik, serta lantai tanpa pelapis (Kodak, 1990).

5. Pencahayaan

Cahaya merupakan pancaran gelombang elektomagnetik yang melayang melewati udara. Illuminasi merupakan jumlah atau kuantitas cahaya yang jatuh ke suatu permukaan. Apabila suatu gedung tingkat illuminasinya tidak memenuhi syarat maka dapat menyebabkan kelelahan mata, sehingga dapat menimbulkan terjadinya kesalahan dalam melakukan pekerjaan serta kelelahan pada indra mata yang terus menerus dapat mengakibatkan gangguan kesehatan pada mata. NAB Surat Edaran Permenaker No. SE01/MEN/1998 tentang besarnya illuminasi yaitu 300-900 lux.

\section{Kebersihan Udara}

Kebersihan udara berkaitan dengan keberadaan kontaminan udara baik kimia maupun mikrobiologi. Sistem ventilasi AC umumnya dilengkapi dengan saringan udara untuk mengurangi atau menghilangkan kemungkinan masuknya zat-zat berbahaya ke dalam ruangan. Untuk ruangan pertemuan atau gedung-gedung dimana banyak orang berkumpul, dan ada kemungkinan merokok, dibuat suatu perangkat hisap udara pada langitlangit ruangan. Sedangkan lubang hisap dibuat di lantai dan cenderung mengisap debu (Arismunandar dan Saito, 2002).

\section{Kebisingan}

Menurut Purdom P.W. (1980) secara fisik suara adalah energi berbentuk getaran yang bergerak dari satu titik dan merambat pada media udara. Suara-suara yang tidak atau kurang dikehendaki dan menimbulkan gangguan disebut kebisingan; hal ini berarti subjektifitas seseorang terhadap suara tertentu atau sensitifitas orang terhadap kebisngan berbeada satu sama lain. Namun secara umum batasan kebisingan ditentukan sesuai dengan peruntukan bangunan.

\section{Bau}

Bau merupakan faktor kualitas udara yang penting. Bau dapat menjadi penunjuk keberadaan suatu zat kimia berbahaya seperti Hidrogen sulfide, Ammonia, dan lainlain. Selain itu bau juga dihasilkan oleh berbagai proses biologi oleh mikroorganisme. Kodisi ruangan yang lembab dengan suhu tinggi dan aliran udara yang tenang biasanya menebarkan bau kurang sedap karena proses pembusukan oleh mikroorganisme (Mukono, 1993).

\section{Ventilasi}

Ventilasi dalam lingkungan kerja ditunjuk untuk: 1) mengatur kondisi kenyamanan ruangan; 2) memperbaharui udara dengan pengenceran udara ruangan pada batas normal; 3) menjaga kebersihan udara dari kontaminan berbahaya. Ventilasi ruangan secara alami didapatkan dengan jendela terbuka yang mengalirkan udara luar ke dalam ruangan, namun selama beberapa tahun terakhir AC (Air Conditioner) menjadi salah satu pilihan.

Mekanisme kerja AC, udara di luar gedung dihisap, didinginkan, kemudian udara yang dingin itu dihembuskan ke dalam ruangan. Terdapat dua jenis AC, yaitu AC sentral dan AC non-sentral. Perbedaan jenis AC non- sentral dan sentral terletak pada volume udara segar yang dipergunakan. Biasanya AC non-sentral hanya memiliki gerakan udara masuk (inlet), sedangkan outlet melalui lubang atau pintu yang sedang dibuka. Sistem ventilasi AC non-sentral memungkinkan masuknya pencemar dari udara luar ke dalam ruangan.

\section{E. Aplikasi Sistem Penyegaran Udara untuk Berbagai Macam Gedung \\ 1. Gedung Kantor. \\ Penyegaran udara gedung kantor diperlukan untuk} memberikan kenyamanan lingkungan kerja bagi para karyawan. Dalam banyak hal penyegaran udara itu juga diadakan untuk melindungi peralatan kantor. Di dalam gedung yang terdiri dari ruangan pribadi dan ruangan pertemuan, sebaiknya terdapat pengatur temperatur dan kelembaban udara atau penyegar udara untuk setiap kelompok ruangan dengan tingkat kegiatan sama.

Sebuah gedung besar dapat dibagi menjadi daerah pinggir, yang dipengaruhi oleh kondisi udara luar dan daerah interior (dalam) yang tidak banyak dipengaruhi oleh kondisi udara luar dan karena selalu ada tambahan kalor (heat gain) di dalam ruangan, boleh dikatakan selalu memerlukan pendinginan. Untuk penyegaran udara gedung kantor sebaiknya pembagian daerah dilakukan berdasarkan titik-titik kardinal, lama kegiatan, adanya ruangan khusus seperti ruangan pertemuan dan sebagainya (Arismunandar dan Saito, 2002).

2. Hotel

Hotel yang terdiri dari ruang tamu, ruangan umum seperti ruang duduk, ruang makan, ruang pertemuan dan sebagainya sebaiknya memiliki sistem penyegaran dilengkapi dengan pengatur temperatur dan kelembaban yang disesuaikan dengan keperluan. Pada hotel yang khusus dipakai untuk keperluan pekerjaan, sebaiknya digunakan ke setiap ruang tamu. Dalam hal tersebut dapat pula digunakan unit kipas udara jenis air penuh, pendingin ruangan yang terpasang pada dinding atau pendingin ruangan jenis pompa kalor (Arismunandar dan Saito, 2002).

\section{F. Perawatan Sistem Pendingin/Penyegar Udara (AC)}

Perawatan sistem pendingin udara meliputi pekerjaan untuk mempertahankan agar semua peralatan yang ada dalam keadaan sebaik-baiknya. Untuk menghindari kerusakan dan kecelakaan, maka semua peralatan dan alat 
keamanan harus diperiksa secara periodik. Pemeriksaan dan perawatan harus meliputi :

1. Membersihkan saluran udara.

2. Terminal rangkaian harus kokoh.

3. Tegangan tali kipas diperiksa.

4. Penyetelan tekanan.

5. Pemeriksaan baut yang kendor.

6. Pemeriksaan kebocoran gas.

7. Membersihkan kotoran dan debu dari pipa pembuangan.

\section{KESIMPULAN}

Dalam penelitian air purifier dengan air sebagai filter untuk kontrol kesehatan lingkungan dapat berfungsi dengan baik dalam waktu 1 jam, untuk melalukan pengukuran debu dan suhu dapat berjalan dengan baik, namun kemudian instalasi listrik yang ada pada alat air purifier terbakar karena kesalahan instalasi listrik, sehingga dalam pengerjaannya diperlukan kehati-hatian sehingga bahan yang terbatas dapat digunakan seefisien mungkin yang meliputi juga unsur-unsur ekonomi, sosial, teknologi dan budaya dalam berbagai dinamikanya, beserta peralatan yang digunakan.

Untuk selanjutnya perlu dilakasanakan penelitian lebih lanjut mengenai air purifier dengan air sebagai filter dan diperlukan seorang tenaga ahli dalam pekerjaan pembuatan alat dan bahan yang digunakan dalam pengerjaannya harus membuat lebih agar lebih mudah dalam pengerjaannya.

\section{DAFTAR PUSTAKA}

Aditama, T. (2002). Manajemen Administrasi Rumah Sakit. Jakarta: UI-Press.

Arismunandar, W, dan Saito, H. (2002). Penyegaran Udara. Jakarta: PT. Pradnya Paramita

National Health and Medical Research Council. (2010). Australian Guidelines for the Prevention and Control of Infection in Health Care, Healthcare Associated Infection Risk Management and Patient Safety Standards : Categorised guidance on recommended practice and legal and professional standards in infection. Canberra: NHMRC - ICG Project Team.

EPA. (1997). Paraquat Dichloride. Environmental Protection Agency Office of Pesticide Programs Special Review Registration Division. Washington DC.

Fardiaz, S. (1992). Polusi Air \& Udara. Yogyakarta: Kanisius.

Heryuni, S. (1993). Kualitas Lingkungan Kerja Perkantoran dan Standarnya. Majalah Hiperkes dan Keselamatan Kerja, Volume XXVI No 2 dan 3. Jakarta: Departemen Tenaga Kerja RI.

Idham, M. (2001). Manajemen Kualitas Udara dalam Gedung Bertingkat. Jakarta.

Kodak. (1990). Ergonomic Design for People at Work. NY: Eastman Kodak Company.
Kusnoputranto, H. (2000). Kesehatan Lingkungan. Jakarta: Fakultas Kesehatan Masyarakat Universitas Indonesia.

Molhave, L.C. (1990). Volatile Organic Compounds and The Sick Building Syndrome, Environmental Toxicans: human exposure and their health effect.

Mukono. (1993). Kualitas Udara Ruangan, Kehidupan Mikroorganisme di dalam Ruangan Frekuensi Terjadinya Infeksi Nosokomial di RSUD Dr.Soetomo Surabaya. Jurnal Lingkungan dan Pembangunan, 4149. Jakarta: LPFEUI.

Purdom, P. (1980). Environmental Health. New York: Academic Press.

United States Environmental Protection Agency, (2002) California Environmental Protection Agency Department of Pesticide Regulation Environmental Monitoring Branch. US.

US EPA. (1991). Methods for Measuring The Acute Toxicity of Effluents and Receiving Waters to Freshwater and Marine Organism: 4th Edition. Unites States: Environmental Protection Agency. 